\title{
Developing a Holistic Understanding \\ of Health and Health Behavior \\ in People Undergoing Resocialization \\ in Prison under the "Active Today, \\ Different Tomorrow"
}

Authors' contribution:

A) conception and design of the study

B) acquisition of data

C) analysis and interpretation of data

D) manuscript preparation

E) obtaining funding

\section{Piotr Łapiński}

Central Training Center of Prison Service in Kalisz, Poland

Higher Vocational State School of President Stanistaw Wojciechowski

in Kalisz, Poland

ABSTRACT

The main purpose of detention in a modern, humanitarian prison system is to bring the prisoners to live in a free society in a manner consistent with applicable laws and morals. The indicators of modernity are also ways and means by which attempts are made to achieve this goal. In many European and non-European prisons, physical culture achievements are commonly used in working with prisoners. They organize programmed resocialization activities for prisoners with a substantial share of physical education and recreational free time activities. Sometimes, prisoners are offered the chance to take their own initiatives to encourage healthy lifestyles.

In addition to teaching, during which the prisoners participate in physical activity, they use interaction with sports authorities in the form of discussion meetings between prisoners and athletes.

Such meetings are also organized at the House of Detention in Inowrocław, which operates a half-open unit for the convicts. These meetings are the part of the activities of "Paragraph", the Olympian club (based at the Inowrocław prison) subject to the Polish Olympic Committee.

The author participated in several such meetings as an invited guest or co-organizer and observed that they are primarily of a recollective character. But it was hard to find in them specific, praxeologically structured and conceptually implemented resocialization interactions. Teleological vagueness initiated the search for the real purpose of these meetings by means of observation. The meetings clearly appeared to have more of an ad hoc (referring to the conditions in prison) than a prospective character (undertaken with a view to the period after release). These findings were the inspiration for the development of the main objectives of a two-step strategy of a change in scenarios of the meetings between the convicts and athletes, the ultimate goal of which was to give them the characteristics of programmed rehabilitation. They defined the procedure for involving sportsmen to accomplish the objectives in the area of mental health and social development and made the selection and development of tools to measure the effects of these interactions.

The article is a report on research designed to determine differences in perception of health, as well as on conducting health activities among those inmates who participated in the program "Active today, different tomorrow" and those who did not participate in it. The study involved 67 penitentiary recidivists. Two question- 
naires by Siegfried Juczyński were used: the List of Health Criteria and Health Behaviour Inventory. The results gave the possibility to formulate important methodological implications for practitioners who involve prominent sportsmen in resocialization. They also proved useful in efforts to create another resocialization program that uses sports activity in resocialization.

KEYWORDS $\quad$ Olympians, sports champions, prisoners, penitentiary resocialization

\section{Introduction}

The analysis of magazine articles about penology shows that regular meetings of prominent sportsmen and prisoners have become an integral element of general resocialization strategy implemented in many prisons (Budny 2010a, 2010b, Szewczak 2010). Similar conclusions can be drawn when following the news on the official website of the Polish system of prison organization (Kurowski 2011, Nitkowski 2011, Pachała 2011, Szargało 2011). Nevertheless, attributing resocialization goals to the meetings has always given rise to some questions about the scope of particular changes in prisoners' attitudes caused by direct involvement of prominent sportsmen. The author's doubts were intensified while being a participant of such meetings. A cursory observation showed that the meetings had had a recollective character rather than an educational one, and there had been no planned resocialization treatment. The answers to the question about an actual realization of resocialization goals by means of such treatment (only about some intentions to do so) has not been found in literature referring to the analyzed prison environment (Marczak 2009, Rejzner 2002). There have been no explanations in the papers entitled "Promotion of health as an important element of system of prison organization" presented by the Olympian Club called "Paragraph" - organizers of such meetings during a scientific conference in 2006 (Budny 2006). The author learned that most prison officials declared their involvement in implementing resocialization goals by organizing the meetings of sportsmen and prisoners. These goals were typically worded on extremely low level of details without emphasizing intermediary or operational goals. The author, who is an educator, wants to find these goals by means of scientific methods, to verify his findings, to particularize the goals, and present some real goals even if they are divergent from the assumed goals.

The preliminary diagnosis (Figure 1) was implemented during the three consecutive meeting of prisoners and sportsmen: June 2, 2010 with Szymon Kołecki, August 31, 2010 with Anna Rogowska, and October 6, 2010 with Robert Maćkowiak at the House of Detention in Inowrocław. In his diagnosis the author used methods such as concealed observation (conducted in the phases of the planning of a meeting, during the meetings, and after them) as well as interviews with penitentiary pedagogues employed in various prisons where the meetings had been organized.

\section{Preliminary diagnosis}

The analysis of documentation drawn up by teachers allowed the insufficient level of details in the goals of interaction assigned to programs subject to the research to be seen. In some programs these goals of interaction were worded on a general level, using terms such as "social re-adaptation", "shaping socially desired attitudes", or "resocialization". However, in most programs, the objectives were set out on a less general level, although still insufficiently detailed. In this group of programs, the goals related to two areas:

- healthy lifestyle of prisoners (if the specific indicators of this style were determined, they were almost exclusively limited to the physical functioning of a human),

- other aspects of the prisoners' life (they were limited either to the principle of fair play or the ability to cooperate in a team).

Operational objectives in the analyzed programs were not determined at all.

Thanks to the analysis of the results of observation, which was to determine the main topics of discussion between prisoners and sportsmen (after dividing topics into categories), the author selected two main topics: memories and exercising guidance. Prisoners are vitally interested in sportsmen's memories, 
especially those that describe interesting and distant places or particular events (Olympic Games, championships, tournaments, etc.). Inmates also evinced an urgent need to obtain from visitors information on the physical aspects of human functioning especially in contexts generally considered to affect fitness. The most important information for prisoners was how to exercise, for how many hours, and what diet is the healthiest one. At the same time their interest in discussing mental health was limited almost exclusively to the factors that may (according to the state of their knowledge) have an impact on mood while being imprisoned. As far as social health is concerned, the discussion was limited to the relation between a particular sportsman and his/her roommate during sports camps or tournaments. It is worth emphasizing that the only initiators of topics connected to social health were sportsmen. At the same time, in their conversation with prison personnel (after the meetings with prisoners), the sportsmen claimed that the meetings were similar to their meetings with members of supporters' clubs. The only difference was that prisoners were much more interested in training advice and the sportsmen's diets.

Interviews with penitentiary pedagogues proved that, in most cases, the catalogue of the expected changes resulting from the meetings of prisoners and sportsmen is limited to motivating prisoners to selfcontrolled behavior. The interviewees also expected prisoners participating in the meetings to be nonconflicting but peaceful in their living area. They used the requirement that if a prisoner wanted to get a permission to participate in the meetings with renowned people, he or she was expected to make additional effort to meet the expectations of the people who gave the permission.

A preliminary diagnosis showed that the resocialization advantage of the meetings of prisoners and sportsmen is rather low when based on such model. It was believed that the meetings were instead of a "recollective character with some elements of exercise coaching" (Figure 1). The results of the preliminary diagnosis made the author think of the insufficient role of sports authorities in the pro-social treatment of prisoners. It also inspired him to take into consideration how to change fixed scenarios for such meetings so as to use them in such a way to provoke changes other than summary ones, which is the essence of the resocialization process. These considerations became the basis for drawing the plan for re-organization of the meetings discussed in this paper.

\section{The plan of double correction}

The actual goals of the meetings of prisoners and sportsmen, which took place in House of Detention in Inowrocław, were based on Model 1 (Figure 1) and focused on improving the self-controlled behavior of prisoners and discipline inside the prison as a result. However, self-controlled behavior of inmates is one of the factors (but not the only one) that determine proper relations in a resocialization institution. One can realize that the primary motivation of an inmate to change his/her behavior is an expectation to be prized; consequently, the change may be of instrumental endurable character (Lobocki 2007, Nowak 2008), and fail to modify his/her behavior (Górski 1985). Moreover, educative environment should be perceived as an essential condition to apply resocialization treatment, rather than its final target. That is why at this stage the author claims that the meetings discussed in this paper can be a source of much wider catalogue of advantages. Stricte educative advantages should be imprinted in axiom-normative system of inmates and reflected in their attitudes and other factors responsible for durability of these changes. That is why the author intended to draw up the double correction plan applied to the process of preparation and the course of meetings of prisoners and sportsmen.

On the level of the meetings taking place according to Model 1 (Figure 1), sportsmen and prisoners were given free choice in discussing particular topics. It gave a spontaneous character to the meetings with the only limitation being to conform to prison regulations. This resulted in the failure to reach the most important goals of resocialization connected to social functioning of a human.

Taking into account the outcome of observation conducted in the preliminary diagnosis, following the intent of verification of the aims of the meetings of convicts and sportsmen included by educators in their documentation, the author assumed that health (whatever it meant to prisoners at first) is an efficient bridge 
leading to discussion - apart from topics connected to human body - on the issues connected to the social functioning of a man.

The starting point for anticipating the effects of interactions between sportsmen and convicts (determined by the preliminary diagnosis) was the way a sportsman was perceived as a person who:

- not always treats his/her own physical health with due care because of priorities set in sports results (McGrath \& Cowan 2008, Sankowski 2001),

- willingly engages himself/herself in pro-social activities, including charity (Cristóbal 2008),

- is claimed to be a real authority for the majority of convicts (Marchewka 2001).

A clearly looming difference between criminals acting to the detriment of society and sportsmen manifesting a tendency to pro-social activities was intended to be the framework of sportsmen's impact on prisoners. The result of this impact would be to change the way of understanding the nature of health by prisoners. It was expected that convicts, to a lesser extent than before, would identify health with physicality and internalize a more holistic way of understanding of health. As a part of this study, a holistic concept of health was used in the sense defined in the Constitution of the World Health Organization, which " $(. .$.$) as the$ first organization took comprehensive account of (holistic) and positive understanding of health (...)" (Borzucka-Sitkiewicz 2006, p. 9). According to this definition, "Health is a state of complete physical, mental and social well-being and not merely the absence of disease or infirmity" (Constitution...) $)^{9}$. It was intended to make convicts not associate health exclusively with the physical health of human functioning, but also show the importance of:

- mental health - so that prisoners wanted to take care of it and to endure the hardships of prison isolation in a better manner, as well as

- the social dimension of health understood in terms of the quality of relationships or "behaviours connected to accomplishing different social roles and performing tasks assigned to the socialization processes" (Bulik \& Ogińska-Juczyński 2010, p. 16).

The state of the prisoners' consciousness could be the basis for their participation in the in-depth discussions aimed at shaping some socially desirable attitudes, in particular, selflessness, sensitivity to the plight of others, and other pro-social attitudes whose realization would be the chance for social compensation.

Recognizing the impossibility of immediate implementation of all necessary changes involving scenarios of meetings with sportsmen and inmates, and guided by the intent of a quick - even if incomplete improvement of the quality of interaction during meetings scheduled immediately after the preliminary diagnosis, the author realized that, in the first place, an ad hoc correction should be done in the way that the meetings should be of a recollective, pro-health character (Figure 1, Model 2). The pro-health program pursued through ad hoc correction was called "Active Today, Different Tomorrow". This name was taken to reflect the intellectual activity of prisoners (reflection) over their obligations and opportunities to make changes in themselves as conceived holistically. The expected result of this activity was a set of positive change the inmates undergo in their ability to take pro-health actions as well as in the axiomatic area. As Pope John Paul II said, prisons "should serve human renewal by giving to those who made a mistake, the opportunity to reflect and change life, which they might turn up again in the life of society" (Ciepły 2009, p. 94). Implementation of the program was to result in changing the way health was perceived by convicts in the direction of the shift from the identification of health with human body to holistic approach. The result of the diagnosis of the recollective, pro-health model of the meetings under the "Active Today, Different Tomorrow" program is the main part of the report on the research presented below.

\footnotetext{
${ }^{9}$ Despite many controversies surrounding the definition of health quoted here (Ogińska-Bulik \& Juczyński 2010 , Seredyńska 2010), it was used because of its simplicity and isolation of only three dimensions of health (including the aspect of public health which is extremely important in resocialization). The intention of the author of "Active Today Different Tomorrow" program was to call for changes in inmates' consciousness: from a bio-somatic understanding to a multi-composed one. In this situation, so as to determine the actual direction of a three-component change, the WHO definition proved to be quite sufficient.
} 


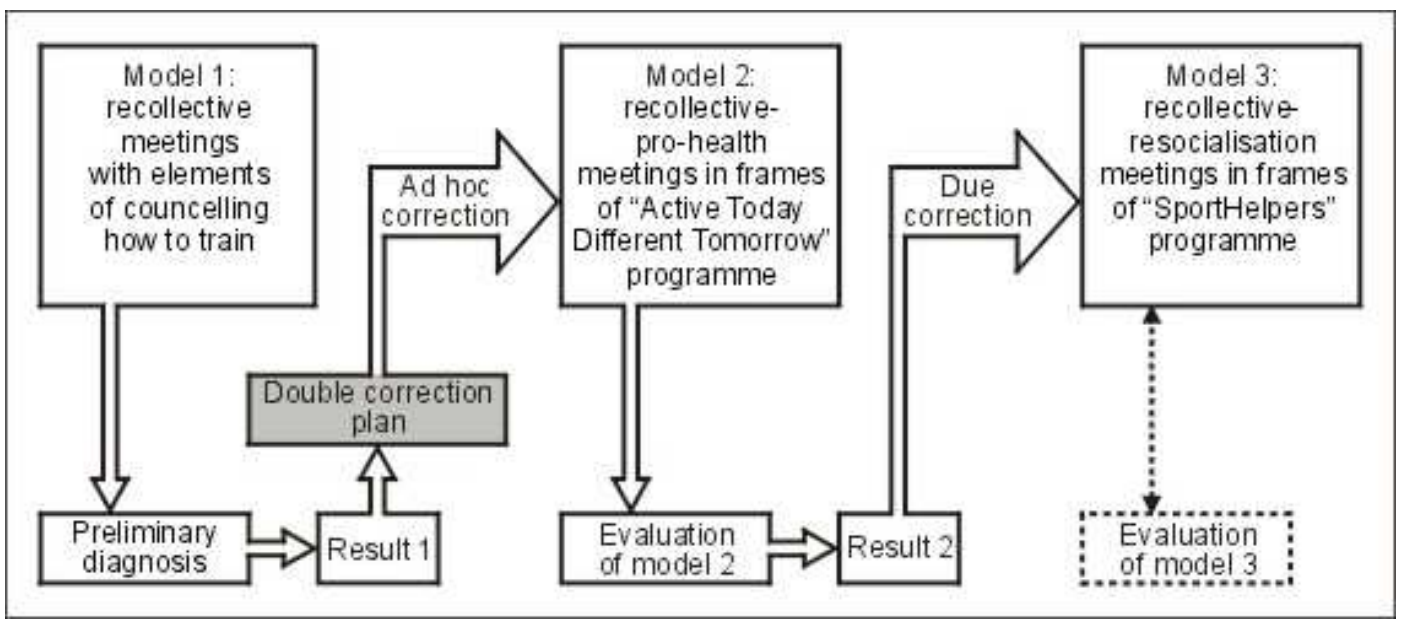

Figure 1. The place and expected results of the plan of double correction of the meetings of prisoners and sportsmen

The ad hoc correction was to diagnose the readiness of sportsmen to being involved in active, programmed (less spontaneous) involvement in resocialization measures, their competence, and their organizational preferences resulting from the fact of limited free time. The correction also aimed at learning about the level of readiness and support given to the program of involving sportsmen in activities other than statutory ones by Polish Olympic Committee. The sportsmen were expected to focus on pro-health and consequently resocialization activity. Before that (when the meetings had been based on Model 1), such a diagnosis was unavailable because sportsmen were not expected to undertake this type of activity. The most important modification implemented in frames of the ad hoc correction was to assign sportsmen to the role of those who provide prisoners with methodologically aimed educative stimuli.

In the second model of the meetings, their spontaneous nature was abandoned by:

- informing a sportsman of the special character of the meeting,

- informing a sportsman about his/her unusual role,

- methodological instructions given to a sportsman.

During the invitation submitted to a particular sportsman he/she was informed that the author's intention was not to organize typical meetings with supporters but meetings of an educative and pro-health character. At this stage, the sportsman was also acquainted with one of the objectives of the program, which was defined as raising prisoners' awareness of the social significance of health and the quality of social functioning to their health. Further involvement of sportsmen in targeted interactions with prisoners took place during the so-called methodological-advisory training conducted by prison personnel. The last training immediately preceded each meeting of the sportsman with the prisoners.

During their training, the sportsmen were informed about the possible and expected (by the organizer) types of activities during the meeting: particular topics to be initiated in conversations, expressing interest in the life of prisoners, motivating prisoners to reflect on their own social functioning, etc. (Preliminary diagnosis showed that sportsmen were accustomed to answering questions, but were not always prepared to ask them).

The diagnosis of meetings was conducted during the meeting and immediately after the meeting. 


\section{Scope of the study, material, and method}

The scope of the research was to determine potential changes in inmates that resulted from their participation in meetings with sportsmen organized at the House of Detention in Inowrocław ${ }^{10}$. In contrast to the preliminary diagnosis, the measurements covered by this research project were taken during subsequent meetings organized on the basis of the model revised by ad hoc correction, the second model included in the framework of the "Active Today, Different Tomorrow" program (Figure 1, Model 2).

In the analyzed period the following meetings of prisoners and sportsmen were organized in House of Detention in Inowrocław:

- December 11, 2010, meeting with Sławomir Kruszkowski,

- February 17, 2011, meeting with Marcin Dołęga,

- April 7, 2011, meeting with the female volleyball team of Atom Trefl Sopot: Paulina Maj, Amaranta Fernandez Navarro, Dorota Świeniewicz, Izabella Bełcik, Neriman Ozsoy, and the president of the club Marek Brandt and Alessandro Chiappini (coach),

- April 13, 2011, meeting with Marek Leśniewski,

- April 26, 2011, meeting with Szymon Ziółkowski.

Additionally, on February 16, 2011, prisoners participated in the meeting with Monika Pyrek during the Athletics Competition called Pedros Cup in Łuczniczka Sports Centre in Bydgoszcz.

The aspects measured were the ways of understanding health by prisoners and their health behavior.

The subjects to the research were only those inmates who had wanted to participate in the meetings with sportsmen organized by "Paragraph" Olympian Club. Because of various variables resulting from the specificity of the place of research, the composition of groups of inmates participating in the meetings was changeable. The surveyed group consisted of prisoners who participated in at least three meetings between December 2010 and April 2011.

The control group consisted of inmates who were willing to participate in the meetings but could not reach their goal due to some other reasons such as a lack of seats, their working hours, classes, etc. The control group was not composed of prisoners who did not participate in the meeting with sportsmen due to disciplinary reasons.

In the study, a scientific procedure based on the ex post facto model was used because the concept of the implementation of stage two, which aimed at measuring the concept of health and pro-health behavior of the surveyed people, appeared while implementing the "Active Today, Different Tomorrow" program (i.e., as a result of discussions with sportsmen pursuing this program). The author decided to employ the confirmation variant of the procedure, as he wanted to determine the influence of a particular (already identified) dependent variable (the participation of inmates in the "Active Today, Different Tomorrow" program). It is worth emphasizing that the meetings were one but not the only source of stimulus creating changes. Before each meeting the prisoners were encouraged to prepare for the meeting (learn about the biography of a sportsman, prepare some questions, etc.). Moreover, they were motivated to actively participate in the meeting by providing them with some materials and information prepared for them.

An additional (hidden) intention in making these texts available was to strengthen the authority of a particular sportsman through impact on the cognitive and emotional realm of convicts' behavior. Information supplied with such an intention - as recommended by Philip Zimbardo and Michael Leippe (2004) - related to both the subject of attitude (sportsman) and the appropriate behavior towards him. Materials were written with the proper care of their emotional appeal. Therefore, they contained information about many achievements of a sportsman and about his/her involvement in activities for health of people in need (requiring expensive surgery, hospice patients, severely injured athletes, etc.). They also contained suggestions to motivate the cognitive activity during a meeting with a sportsman. The authority of a

\footnotetext{
${ }^{10}$ In this House of Detention there are both half-open and open units.
} 
sportsman, reinforced (fixed) in this way, was to be used in implementing the "Active Today, Different Tomorrow" program.

The action plan of the Olympian Club called "Paragraph" was to:

- provide the implementation of the need for membership of the program participants as an alternative to membership in a criminal subculture,

- create social environment conducive to interactions with the mechanisms of social support and incentives to make further efforts - in this case, for health (Prochaska, Norcross, \& DiClemente 2008).

Social influence processes, which were used in the interactions with convicts (during meetings), were carried out in both the interpersonal and persuasive manner (Zimbardo \& Leippe 2004). In the consultations between prison staff and sportsmen preceding the meetings of inmates and sportsmen, they discussed the options of how to use the strategy appealing to fear or how to extract commitments (op. cit.). In the methods used to have an impact on prisoners (those carried out with the materials as described above and performed by sportsmen in direct contact with prisoners), they tried to use the principle of social proof, which is particularly effective "in determining which conduct is proper and which is not" (Cialdini 2009, p. 134).

Two working hypotheses were formed:

h1: participants of the meetings with sportsmen tend to perceive health in a more complementary way (including all measured aspects of it) when compared to non-participants, who identified health with physical sphere of human functioning;

h2: pro-health attitude is stronger with participants of the meetings with sportsmen than with nonparticipants.

In the study the following psychological tests were used:

- List of Health Criteria (LHC)

- Health Behaviour Inventory (HBI)

The List of Health Criteria is a tool of measuring "activities which modify pro-health behavior in treatment and rehabilitation" (Juczyński 2001, p. 126). The author chose the Health Behaviour Inventory because it is a tool of measuring the direction in which pro-health behavior can be modified (op. cit., p. 121).

The complementary tool in the study was a survey consisting of five questions relating to the quality of relations between a respondent and other people. To make the study simple, the questions were formed so as the answers could be given in a similar way to the HBI test where:

- 1 means "almost never",

- 2 means "rarely",

- 3 means "from time to time",

- 4 means "often",

- 5 means "almost always".

In comparative statistical analysis, the Mann-Whitney U test was used.

\section{Results}

The HBI test begins with the statement "Being healthy means to me". Various endings of this statement were listed below. The participants were to assign a point value to each of these statements.

Between prisoners participating in the meetings with sportsmen and prisoners not participating in these activities, there were no statistically significant differences in terms of indicators showing the way of understanding the essence of health contained in the LHK test (Table 1).

Inmates rarely associated "being healthy" with the claims about nutrition (and during the meetings such topics of conversation were initiated by them). No one associated being healthy with "drink little amounts of alcohol or none", for only a few participants it meant "have a proper weight" and "have a good 
diet". The highest-rated statement was: "feel happy most of the time" and "be able to solve one's own problems".

Table 1. The comparative analysis of the surveyed groups of prisoners based on the LHK with reference to their attitudes to health

\begin{tabular}{|c|c|c|c|c|c|c|c|c|c|}
\hline \multirow{3}{*}{\multicolumn{2}{|c|}{ 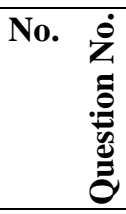 }} & \multirow[t]{3}{*}{ Statement } & \multirow{3}{*}{$\begin{array}{l}\text { Definition } \\
\text { of health }\end{array}$} & \multicolumn{4}{|c|}{ mean } & \multirow[t]{3}{*}{$\mathbf{Z}$} & \multirow[t]{3}{*}{$\mathbf{p}$} \\
\hline & & & & \multicolumn{2}{|c|}{$\begin{array}{c}\text { Group of } \\
\text { respondents } \\
{[\mathrm{N}=36]}\end{array}$} & \multicolumn{2}{|c|}{$\begin{array}{l}\text { Control } \\
\text { group } \\
{[\mathbf{N}=31]}\end{array}$} & & \\
\hline & & & & M & SD & M & SD & & \\
\hline 1 & 2 & feel happy for most of the time & state & 1,22 & 2,10 & 1,36 & 2,07 & $-0,52$ & 0,61 \\
\hline 2 & 4 & be able to solve one's own problems & process & 1,22 & 1,99 & 0,65 & 1,54 & 1,06 & 0,29 \\
\hline 3 & 18 & be responsible & target & 1,17 & 1,86 & 0,58 & 1,18 & 0,98 & 0,24 \\
\hline 4 & 16 & be able to adapt to changes in life & process & 1,11 & 1,72 & 0,77 & 1,43 & 0,63 & 0,53 \\
\hline 5 & 20 & have all parts of body & condition & 1,11 & 1,75 & 1,97 & 1,89 & $-1,91$ & 0,06 \\
\hline 6 & 23 & feel good & state & 1,00 & 1,72 & 1,23 & 1,71 & $-0,92$ & 0,36 \\
\hline 7 & 8 & not to smoke & result & 0,83 & 1,48 & 0,55 & 1,50 & 0,79 & 0,43 \\
\hline 8 & 17 & be glad of life & state & 0,83 & 1,32 & 0,45 & 1,21 & 1,26 & 0,21 \\
\hline 9 & 1 & live a long life & target & 0,72 & 1,54 & 0,74 & 1,56 & $-0,23$ & 0,82 \\
\hline 10 & 14 & $\begin{array}{l}\text { not to be ill, except the flue or } \\
\text { indigestion }\end{array}$ & condition & 0,72 & 1,43 & 0,32 & 0,87 & 0,75 & 0,45 \\
\hline 11 & 3 & have good relations with other people & process & 0,67 & 1,39 & 0,65 & 1,70 & 0,45 & 0,65 \\
\hline 12 & 12 & not to suffer physical pain & condition & 0,61 & 1,32 & 1,10 & 1,72 & $-1,18$ & 0,24 \\
\hline 13 & 22 & have a job, various interests & result & 0,61 & 1,44 & 0,39 & 0,88 & $-0,01$ & 0,99 \\
\hline 14 & 24 & hardly ever see a doctor & condition & 0,56 & 1,23 & 0,39 & 1,26 & 0,99 & 0,32 \\
\hline 15 & 6 & care for relax and sleep & result & 0,50 & 1,13 & 0,00 & 0,00 & 1,56 & 0,12 \\
\hline 16 & 11 & be in good mood & condition & 0,44 & 1,13 & 0,71 & 1,35 & $-0,64$ & 0,52 \\
\hline 17 & 13 & $\begin{array}{l}\text { be able to work without tension or } \\
\text { stress }\end{array}$ & process & 0,39 & 1,13 & 1,03 & 1,54 & $-1,41$ & 0,16 \\
\hline 18 & 15 & have healthy eyes, hair, and skin & condition & 0,33 & 1,01 & 0,45 & 1,21 & $-0,15$ & 0,88 \\
\hline 19 & 5 & have a good diet & result & 0,28 & 0,57 & 0,32 & 0,87 & 0,48 & 0,63 \\
\hline 20 & 10 & hardly ever take medicine & condition & 0,28 & 0,82 & 0,00 & 0,00 & 0,78 & 0,44 \\
\hline 21 & 21 & $\begin{array}{l}\text { accept oneself, know one's own } \\
\text { advantages and disadvantages }\end{array}$ & target & 0,28 & 1,16 & 0,26 & 0,77 & $-0,47$ & 0,64 \\
\hline 22 & 19 & be able to control feelings and impulses & process & 0,22 & 0,93 & 0,32 & 0,87 & $-0,47$ & 0,64 \\
\hline 23 & 9 & have proper weight & result & 0,17 & 0,70 & 0,07 & 0,25 & $-0,04$ & 0,97 \\
\hline 24 & 7 & drink little amounts of alcohol or none & result & 0,00 & 0,00 & 0,39 & 1,20 & $-0,68$ & 0,50 \\
\hline
\end{tabular}

Table 2 contains the results of the general index of health behavior, expressed on a Sten scale, measured with the Health Behavior Inventory. This level is significantly higher in participants of the meetings with sportsmen, although only marginally above the average value (4 Sten).

Table 2. The comparative analysis of groups of prisoners with reference to general index of pro-health behavior, presented in the Sten scale

\begin{tabular}{|c|c|c|c|c|c|c|}
\hline \multirow[t]{3}{*}{ Index } & \multicolumn{4}{|c|}{$\begin{array}{c}\text { Participation in meetings with } \\
\text { sportsmen }\end{array}$} & \multirow[t]{3}{*}{$\mathbf{Z}$} & \multirow[t]{3}{*}{$\mathbf{p}$} \\
\hline & \multicolumn{2}{|c|}{$\begin{array}{l}\text { Participants } \\
{[\mathbf{N}=36]}\end{array}$} & \multicolumn{2}{|c|}{$\begin{array}{l}\text { Non-participants } \\
{[\mathbf{N}=\mathbf{3 1}]}\end{array}$} & & \\
\hline & $\begin{array}{c}\text { M } \\
\text { [sten] }\end{array}$ & SD & $\begin{array}{c}\text { M } \\
\text { [sten] }\end{array}$ & SD & & \\
\hline general index of pro-health behavior & 4,31 & 1,41 & 3,39 & 1,86 & 2,58 & 0,01 \\
\hline
\end{tabular}

The Health Behavior Inventory also provides the ability to measure the four categories of pro-health behavior whose names were placed in the first column of Table 3 .

The highest values in both groups were recorded in the category of "positive mental attitude". The statistically significant difference was only recorded in the category of "good nutrition habits". In this 
category pro-health behavior was at a higher level in convicts participating in the meetings with sportsmen. In the other three categories, there were no significant differences.

Table 3. The comparative analysis of the surveyed groups of prisoners with reference to pro-health behavior measured in a point scale

\begin{tabular}{|c|c|c|c|c|c|c|}
\hline \multirow[t]{3}{*}{ Index } & \multicolumn{4}{|c|}{$\begin{array}{c}\text { Participation in meetings with } \\
\text { sportsmen }\end{array}$} & \multirow[t]{3}{*}{$\mathbf{Z}$} & \multirow[t]{3}{*}{$\mathbf{p}$} \\
\hline & \multicolumn{2}{|c|}{$\begin{array}{l}\text { Participants } \\
{[\mathrm{N}=36]}\end{array}$} & \multicolumn{2}{|c|}{$\begin{array}{c}\text { Non- } \\
\text { participants } \\
{[\mathbf{N}=\mathbf{3 1}]}\end{array}$} & & \\
\hline & $\begin{array}{c}\mathrm{M} \\
{[\mathrm{pts}]}\end{array}$ & $\mathrm{SD}$ & $\begin{array}{c}\mathrm{M} \\
{[\mathrm{pts}]}\end{array}$ & $\mathrm{SD}$ & & \\
\hline Good nutrition habits & 2,62 & 0,69 & 2,25 & 0,59 & 2,23 & 0,03 \\
\hline Prophylaxis behavior & 2,69 & 0,50 & 2,53 & 0,92 & 1,84 & 0,07 \\
\hline Positive mental attitude & 3,38 & 0,76 & 3,17 & 0,55 & 1,52 & 0,13 \\
\hline Healthy practices & 3,15 & 0,59 & 2,94 & 0,60 & 1,56 & 0,12 \\
\hline
\end{tabular}

Analysis of the significance of differences was also carried out separately for each of the 24 statements included in the HBI test (Table 4), which showed significantly higher levels of selected health behavior associated with mental health (Statements 11 and 19) and with healthy eating (Statement 5 and 13) in the group examined.

Table 4. The comparative analysis of the surveyed groups of prisoners with reference to answers given to particular statements included in the HBI test

\begin{tabular}{|c|c|c|c|c|c|c|c|c|}
\hline \multirow[t]{3}{*}{ No. } & \multirow{3}{*}{$\begin{array}{l}\dot{0} \\
\dot{z} \\
\dot{0} \\
\dot{0} \\
\dot{\theta}\end{array}$} & \multirow[t]{3}{*}{ Statement } & \multicolumn{4}{|c|}{ mean } & \multirow[t]{3}{*}{$\mathbf{Z}$} & \multirow[t]{3}{*}{$\mathbf{p}$} \\
\hline & & & \multicolumn{2}{|c|}{$\begin{array}{c}\text { Group of } \\
\text { respondents } \\
{[\mathrm{N}=36]}\end{array}$} & \multicolumn{2}{|c|}{$\begin{array}{c}\text { Control } \\
\text { group } \\
{[\mathbf{N}=31]}\end{array}$} & & \\
\hline & & & $\mathbf{M}$ & SD & $\mathbf{M}$ & SD & & \\
\hline 1 & 23 & I think positively & 4,17 & 0,91 & 4,29 & 1,01 & $-0,78$ & 0,44 \\
\hline 2 & 4 & I relax enough & 3,89 & 1,21 & 3,87 & 1,09 & 0,25 & 0,80 \\
\hline 3 & 15 & I have friends and stable family life & 3,72 & 1,43 & 3,61 & 1,09 & 0,72 & 0,47 \\
\hline 4 & 2 & I avoid colds & 3,61 & 1,18 & 3,74 & 0,97 & $-0,26$ & 0,79 \\
\hline 5 & 19 & $\begin{array}{l}\text { I avoid such feelings as anger, anxiety and } \\
\text { depression }\end{array}$ & 3,56 & 1,28 & 2,71 & 1,19 & 2,62 & $\mathbf{0 , 0 1}$ \\
\hline 6 & 16 & I get enough Steep & 3,33 & 1,07 & 3,61 & 1,15 & $-1,02$ & 0,31 \\
\hline 7 & 9 & I care about proper nutrition & 3,28 & 1,06 & 2,84 & 1,16 & 1,40 & 0,16 \\
\hline 8 & 10 & $\begin{array}{l}\text { I comply with medical recommendations connected } \\
\text { to my treatment }\end{array}$ & 3,28 & 1,26 & 2,58 & 1,36 & 2,20 & $\mathbf{0 , 0 3}$ \\
\hline 9 & 7 & I avoid situations that affect me depressingly & 3,22 & 1,33 & 3,48 & 1,06 & $-0,73$ & 0,47 \\
\hline 10 & 8 & I avoid overwork & 3,22 & 1,05 & 2,68 & 1,17 & 1,84 & 0,07 \\
\hline 11 & 11 & I try to avoid too strong emotions, stress and tension & 3,00 & 1,22 & 2,36 & 0,99 & 2,09 & $\mathbf{0 , 0 4}$ \\
\hline 12 & 24 & I avoid excessive physical exertion & 3,00 & 0,96 & 2,36 & 1,05 & 2,23 & $\mathbf{0 , 0 3}$ \\
\hline 13 & 1 & I eat lots of fruit and vegetables & 2,89 & 1,06 & 2,90 & 0,91 & 0,03 & 0,98 \\
\hline 14 & 12 & I control my weight & 2,78 & 1,29 & 2,74 & 1,51 & 0,16 & 0,87 \\
\hline 15 & 22 & $\begin{array}{l}\text { I try to obtain medical information and understand } \\
\text { the causes of health and disease }\end{array}$ & 2,78 & 1,33 & 2,23 & 1,50 & 1,79 & 0,07 \\
\hline 16 & 13 & I avoid eating food with preservatives & 2,72 & 1,30 & 1,45 & 0,72 & 4,00 & $\mathbf{0 , 0 0}$ \\
\hline 17 & 20 & I limit smoking & 2,67 & 1,47 & 2,36 & 1,56 & 1,26 & 0,21 \\
\hline 18 & 3 & $\begin{array}{l}\text { I seriously treat the instructions of people who } \\
\text { express their concern about my health }\end{array}$ & 2,61 & 1,18 & 2,55 & 1,34 & 0,37 & 0,72 \\
\hline 19 & 5 & $\begin{array}{l}\text { I limit the consumption of products such as animal } \\
\text { fat, sugar }\end{array}$ & 2,56 & 1,28 & 1,87 & 0,81 & 2,16 & $\mathbf{0 , 0 3}$ \\
\hline 20 & 18 & I try to learn how other people diseases & 2,56 & 1,18 & 3,03 & 1,45 & $-1,31$ & 0,19 \\
\hline 21 & 17 & I avoid salt and highly salted food & 2,44 & 1,32 & 2,48 & 1,29 & $-0,29$ & 0,77 \\
\hline 22 & 6 & $\begin{array}{l}\text { I have recorded telephone numbers of emergency } \\
\text { services }\end{array}$ & 1,94 & 1,41 & 1,97 & 1,68 & 0,49 & 0,62 \\
\hline 23 & 14 & I regularly go to the medical examination & 1,94 & 1,19 & 1,65 & 1,08 & 1,37 & 0,17 \\
\hline 24 & 21 & I eat whole wheat bread & 1,83 & 1,08 & 1,97 & 1,22 & $-0,29$ & 0,77 \\
\hline
\end{tabular}


Table 5 contains data gathered using a questionnaire and related to selected aspects of social functioning of respondents. Statistically significant differences were observed in only two categories:

- participants of the meetings with sportsmen were significantly more likely to have a sense of being understood, they notified their educators of problems, while

- participants in these meetings significantly more frequently admitted that they get irritated by people with whom they should cooperate because of their duties.

Table 5. The comparative analysis of the surveyed groups of prisoners with reference to selected aspects of interpersonal relations in prison

\begin{tabular}{|c|c|c|c|c|c|c|c|}
\hline \multirow[t]{3}{*}{ No. } & \multirow[t]{3}{*}{ Question in the survey } & \multicolumn{4}{|c|}{$\begin{array}{l}\text { Participation in meetings with } \\
\text { sportsmen }\end{array}$} & \multirow[t]{3}{*}{$\mathbf{Z}$} & \multirow[t]{3}{*}{$\mathbf{p}$} \\
\hline & & \multicolumn{2}{|c|}{$\begin{array}{l}\text { Participants } \\
{[\mathrm{N}=36]}\end{array}$} & \multicolumn{2}{|c|}{$\begin{array}{c}\text { Non- } \\
\text { participants } \\
{[\mathrm{N}=31]}\end{array}$} & & \\
\hline & & $\mathbf{M}$ & SD & $\mathbf{M}$ & SD & & \\
\hline 1 & $\begin{array}{l}\text { My relatives disapprove situations when I wreak my tension } \\
\text { (stress) on them. }\end{array}$ & 2,06 & 1,04 & 1,90 & 1,01 & 0,59 & 0,56 \\
\hline 2 & $\begin{array}{l}\text { I am in bad mood when I wake up and have to start a new } \\
\text { day in prison. }\end{array}$ & 2,22 & 1,10 & 2,29 & 1,27 & $-0,09$ & 0,93 \\
\hline 3 & $\begin{array}{l}\text { I get annoyed with people with whom I should co-operate } \\
\text { because of our common duties. }\end{array}$ & 2,28 & 1,06 & 1,77 & 1,06 & 2,10 & 0,04 \\
\hline 4 & I do not curse in the presence of women. & 2,00 & 1,12 & 2,68 & 1,47 & $-1,72$ & 0,09 \\
\hline 5 & $\begin{array}{l}\text { When I report on a particular problem to my pedagogues I } \\
\text { usually feel they understand me. }\end{array}$ & 2,69 & 1,09 & 2,16 & 1,13 & 2,06 & 0,04 \\
\hline
\end{tabular}

\section{Discussion and conclusions}

There are different ways of perceiving the essence of resocialization (Stańdo-Kawecka 2010, Ambrozik 2006). Some educators working in resocialization, in their attempt to clarify this concept, make analogies to the pedagogy of health using terms such as "disease" (in relation to demoralization and social maladjustment), "recovery" (in relation to the process of resocialization), or "treatment" as synonym for reducing pathological behavior (Górski 1985, Machel 2008, Utrat-Milecki 2003). There are doubts and disputes arising from them as to the validity of this way of understanding the nature of resocialization (Pytka 2005). Sometimes, however, the authors show their attachment to the invalid biological concepts of health.

Although one can find weaknesses in concepts explaining the essence of resocialization derived from health education, it would be difficult to find arguments contradicting the validity of the idea of shaping health-related attitudes among resocialized people without settling on whether it is a simple resocialization or health education.

The perception of health and the consequent health behavior are in fact an important indicator of the quality of adapting to life in society, and in this particular area of prison inmates often show significant educative deficits.

In the process of drawing conclusions from test results, the author considered the fact that:

- the effects of activity of the Olympian Club "PARAGRAPH" in the form of meetings of inmates with convicts and their natural intensity were measured (no additional meetings were organized for the purpose of this study),

- the meetings during which measurement was taken, were held in accordance with the assumptions of the "Active Today, Different Tomorrow" program (Figure 1, Model 2).

Conclusions were drawn in the intention of improving the effectiveness of pro-health impacts resulting from the "Active Today, Different Tomorrow" program and with a view to developing the basic assumptions of another program (called SportHelpers) aimed at involving inmates in pro-social activity. 
The analysis of the results leads to the conclusion that the meetings of prisoners with sportsmen organized in frames of "Active Today, Different Tomorrow" program:

1. Do not cause significant changes in the way health is understood by prisoners.

2. Caused only minimal change in health behavior (especially in relation to dietary practices), but also

3. May indirectly contribute to enhancing the effects of resocialization by improving interpersonal relationships between educators and prisoners.

Prisoners participating in the meetings with sportsmen tended to initiate topics concerning the improvement of nutrition and health behaviors included in the category of "good nutrition habits." At the same time these respondents demonstrated low-level of associating "being healthy" with the statements of the LHC concerning diet which proves that their motives to obey principles of proper nutrition are other than health-oriented. The high level of interest in physical fitness can be the evidence that observance of certain principles of nutrition by inmates is a part of the strategy making.

Taking into consideration conclusions 1 and 2, it is worth considering the actual role of sports champions as initiators of pro-health interactions. Indeed, they are frequently people prepared to bear the risk of injury to overcome the limits of their motor skills especially in a situation that creates the possibility of achieving a better result in sport, a higher score, etc. However, it seems that there are areas of health-related activities in which sportsmen meeting prisoners can make an effective impact on inmates. These include, among others, activities popularizing nicotine abstinence, as demonstrated by independent (arising the interest of the convicts) initiatives taken by sportsmen during the meetings with the convicts. Consequently, in the future:

4. Research initiatives should be taken to separate these elements of their life style in which sports champions can lead an effective pro-health interactions among the prisoners.

5. Organizational efforts should be made to reinforce some symbolic attributes of the athlete's authority (other than related to titles), including his attire (Cialdini 2009). For this purpose one should ensure that:

- athletes use the national team sweatsuits during the meetings,

- the venue is decorated with national symbols (colors),

- a multimedia presentation usually displayed prior to the meeting, includes photographs of the athlete's positive relationships with famous people, and

- during the meetings the sportsmen themselves recount memories showing their positive relationships with famous people.

6. Some efforts should be taken to increase the intensity of contact between sportsmen and inmates participating in "Active Today, Different Tomorrow" program so as to stimulate changes. In addition to activities aimed at increasing the frequency of meetings, one should consider using email for communication between athletes and convicts (sending queries or requests for opinions, collectively developed by inmates, referring to policies used by the Paragraph Club).

7. One should modify the organization and conduct of the meetings to enable better use of the involvement processes and the reward for changing health behavior of convicts (Prochaska, Norcross, $\&$ DiClemente 2008).

- to take advantage of the involvement process, before the meeting one should explain the nature of such meetings to athletes and motivate them to ask prisoners questions about the scope of changes they plan in the health behavior. It is also important so as sportsmen emphasize the importance of such obligations, give signals to obey them, and, if deemed appropriate, made those commitments public among the other members of the Paragraph Club. 
- activity of inmates undertaken in framework of the "Active Today, Different Tomorrow" program should be subject to continuous monitoring and the desired behavior should be rewarded. Monitoring results should be reflected in the prisoner's personal file.

Driven by the intention to increase the usefulness of "Active Today, Different Tomorrow" program in resocialization, in the future:

8. Actions should be taken to increase the level of activity of prisoners in its various areas in connection with the visit of a sportsman in prison, so as causing changes stimuli have an impact on prisoners between, during, and after the meeting with a sportsman.

If you are tempted to do an analogy between resocialization activity and health education or health promotion -

9. One should search for opportunities to prepare sportsmen for such meetings with the convicts so as the interactions referred to all areas of inmates' health in a similar way.

Topics discussed during the meetings and the lives of sportsmen (not only by observation) show their above-average readiness to take actions to help those in need. Many of the sportsmen mentioned their personal support for various charities: some of them, for example, gave some of their Olympic medals for the charity auctions. These topics were not addressed in the context of the possibility of involving convicts in charity. Meanwhile, some prisoners may show the need for specific social compensation. For others there may be possibility of intentional formation of such a need (including the active participation of a sportsman).

Therefore,

10. One should consider the opportunity to prepare sportsmen to motivate prisoners to pro-social activity, especially to offer various kinds of assistance for those in need.

Due to the importance of pro-social activity of inmates for their resocialization process

11. One should develop a different pattern of meetings of convicts with sportspeople whose main objective would be to motivate prisoners to pro-social activity.

12. In the future, one should carefully consider the possibility of conducting meetings of sportsmen and convicts based on two independent models: a pro-health one (in frames of "Active Today, Different Tomorrow" program after implementing the comments contained in the conclusions numbers 4 to 9) and a pro-social one (called SportHelpers as already proposed) - according to the personal competences of individual sportsman and educational deficits of the inmates participating in these meetings.

\section{REFERENCES}

Ambrozik, W. (2006). Pedagogika resocjalizacyjna /Resocialisation pedagogy/. In B. Śliwerski (Ed.), Pedagogika. Subdyscypliny wiedzy pedagogicznej /Pedagogy. Sub-disciplines of pedagogical knowledgel (pp. 280-294). Gdańsk: GWP.

Borzucka-Sitkiewicz, K. (2006). Promocja zdrowia i edukacja zdrowotna /Promotion of health and health education/. Kraków: Impuls.

Budny, M. (2006). Oddziaływanie przez sport na przykładzie Klubu Olimpijczyka PARAGRAF działającego przy Areszcie Śledczym w Inowrocławiu /The impact of sport on the example of PARAGRAPH Olympian Club operating at the Remand Centre in Inowrocław/. In K. Klukowski, P. Łapiński, A. Wiza \& A. Kaczmarek (Eds.), Promocja zdrowia we wspótczesnym więziennictwie /Promotion of health in the modern prison system/ (pp. 190-196). Kalisz: COSSW w Kaliszu, PTNARiT, PTNKF Sekcja Kultury Fizycznej w Wojsku.

Budny, M. (2010a). Olimpijczyk w areszcie /An Olympian in the remand centre/. Forum Penitencjarne, 07(XIII), 31.

Budny, M. (2010b). Mistrzyni w Inowrocławiu /A champion in Inowrocław/. Forum Penitencjarne, 10(XIII), 31.

Cialdini, R.B. (2009). Wywieranie wptywu na ludzi. Teoria i praktyka / Influence on people. Theory and Practice. Nowe poszerzone wydanie. Przeł. B. Wojciszke. Gdańsk: GWP. 
Ciepły, F. (2009). Cele kary kryminalnej w świetle nauczania Jana Pawła II / The objectives of criminal punishment in the light of intuition of John Paul II/. In P. Marzec \& J. Nikołajew (Eds.), Osoba i dzieło Ojca Świętego Jana Pawta II /The person and work of the Pope John Paul II/ (pp. 89-101). Tomaszów Lubelski - Lublin: Wyd. Polihymnia.

Ciosek, M. (1996). Człowiek w obliczu izolacji więziennej /The man facing isolation in prion/. Gdańsk: Stella Maris.

Constitution of The World Health Organization (1946). Retrieved January 20, 2012, from: http://www.who.int /governance/eb/constitution/en/.

Cristóbal C. (2008, December). The goalkeeper defeated Rafa Nadal in the match against Malaria. Retrieved November 20, 2011, from: http://www.realmadrid.com/cs/Satellite/en/1202757858461/noticia/ Noticia/Iker_charitable_challenge.htm

Górski, S. (1985). Metodyka resocjalizacji /Resocialisation methodology/. Warszawa: IWZZ.

Juczyński, Z. (2001). Narzędzia pomiaru w promocji i psychologii zdrowia /Measuring tools in the promotion and health psychology/. Warszawa: PTP.

Kurowski, J. (2011, February) Marcin Urbaś z wizyta w poznańskim areszcie /Marcin Urbaś visiting the detention house in Poznań/. Retrieved September 01, 2011, from http://sw.gov.pl/pl/okregowy-inspektorat-sluzby-wieziennejpoznan/areszt-sledczy-poznan/news,2085, marcin-urbas-z-wizyta-w.html.

Łobocki, M. (2007). Teoria wychowania w zarysie /Theory of education at a glancel. Kraków: Impuls.

Machel, H. (2003). Więzienie jako instytucja karna i resocjalizacyjna /Prison as a penal and resocialization institution/. Gdańsk: Arche.

Machel, H. (2008). Sens i bezsens resocjalizacji penitencjarnej - casus polski /Sense and nonsense of penitentiary resocialization: a Polish casus/. Kraków: Impuls.

Marchewka, A. (2001). Wychowanie fizyczne specjalne /Special physical education/. Kraków: AWF.

Marczak, M. (Ed.) (2009). Resocjalizacyjne programy penitencjarne realizowane przez stużbę więzienna w Polsce /Penitentiary programmes of resocialization implemented by prison service in Poland/. Kraków: Impuls.

McGrath J.C., Cowan D.A. (2008). Drugs in Sport. British Journal of Pharmacology, 154, 493-495.

Nitkowski, R. (2011, April). Mistrz olimpijski, mistrz świata, Europy i wielokrotny mistrz Polski - Leszek Blanik z wizyta $w$ wejherowskim areszcie /Olympic Champion, World and European Champion, multiple champion of Poland Leszek Blanik visiting the detention house in Wejherowo/. Retrieved September 01, 2011, from http://sw.gov.pl/pl/okregowy-inspektorat-sluzby-wieziennej-gdansk/areszt-sledczy-wejherowo /news,2642,mistrzolimpijski-mistrz.html.

Nowak, M. (2008). Teorie i koncepcje wychowania /Theory and the concept of education/. Warszawa: Wydawnictwa Akademickie i Profesjonalne.

Ogińska-Bulik, N. \& Juczyński, Z. (2010). Osobowość, stres a zdrowie /Personality, stress and health/. Wydanie II uzupełnione. Warszawa: Difin.

Pachała, R. (2011, June). Sportowiec w zielonogórskim areszcie /An athlete in a detention house in Zielona Góra/. Retrieved September 01, 2011, from http://sw.gov.pl/pl/okregowy-inspektorat-sluzby-wieziennej-poznan/aresztsledczy-zielona-gora/news, 4028, sportowiec-w-zielonogorskim.html.

Prochaska, J. O., Norcross, J. C. \& Diclemente, C. C. (2008). Zmiana na dobre /Change for good/. Przeł. A. Majcherczyk. Warszawa: Instytut Amity.

Pytka, L. (2005). Pedagogika resocjalizacyjna. Wybrane zagadnienia teoretyczne, diagnostyczne $i$ metodyczne /Resocialisation pedagogy. Selected theoretical, diagnostic and methodological issues/. Warszawa: Akademia Pedagogiki Specjalnej.

Rejzner, A. (Ed.) (2002). Penitencjarna kultura fizyczna /Penitentiary physical culture/. Warszawa: Uniwersytet Warszawski.

Sankowski, T. (2001). Wybrane psychologiczne aspekty aktywności sportowej /Some psychological aspects of sport activity/. Poznań: AWF w Poznaniu.

Seredyńska, D. (2010). Od koncepcji zdrowia do edukacji zdrowotnej /From the concept of health to health education/. In M. Kuchcińska \& E. Kościńska (Eds.), Konteksty zdrowia i edukacji zdrowotnej /The contexts of health and health education/ (pp. 11-37). Bydgoszcz: Wydawnictwo Uniwersytetu Kazimierza Wielkiego w Bydgoszczy.

Stańdo-Kawecka, B. (2010). O koncepcji resocjalizacji w polskiej literaturze naukowej polemicznie /The polemics on the concept of resocialization in Polish literature. Probacja, 1, 108-124.

Szargało, P. (2011, April). Elana za kratami /Elana behind bars/. Retrieved September 01, 2011, from http://sw.gov.pl/pl/okregowy-inspektorat-sluzby-wieziennej-bydgoszcz/areszt-sledczy-torun/news,2635, elana -zakratami.html.

Szewczak, T. (2010). Nastula w Barczewie /Nastula in Barczewo/. Forum Penitencjarne, 09 (XIII), 31. 
Utrat-Milecki, J. (2003). Kontekst kulturowy koncepcji penologicznych /Cultural context of the penology concepts/. In T. Bulenda \& R. Musidłowski (Eds.), System penitencjarny $i$ postpenitencjarny $w$ Polsce /Penitentiary and postpenitentiary system in Poland/ (pp. 36-76). Warszawa: Instytut Spraw Publicznych.

Zimbardo, P.G. \& Leippe, M.R. (2004). Psychologia zmiany postaw i wptywu społecznego /Psychology of changes in attitudes and social influence/. Przeł. P. Kwiatkowski. Poznań: Zysk i S-ka.

AUTHOR'S ADDRESS:

Piotr Łapiński

Centralny Ośrodek Szkolenia Służby Więziennej w Kaliszu

ul. Wrocławska 193-195

62-800 Kalisz

Poland

Email: piotrzkalisza@interia.pl 